\title{
Mobile-Learning Platform for the Development of Entrepreneurial Competences of the Students
}

\author{
https://doi.org/10.3991/ijim.v15i09.20225 \\ Nataliya Tretyakova ${ }^{(凶)}$, Anton Lyzhin, Elena Chubarkova \\ Russian State Vocational Pedagogical University, Ekaterinburg, Russian Federation \\ tretyakova.naterambler.ru \\ Mafura Uandykova \\ Omsk State University by F.M. Dostoevsky, Omsk, Russian Federation \\ Marina Lukiyanova \\ Financial University under the Government of the Russian Federation, \\ Moscow, Russian Federation
}

\begin{abstract}
The aim of the study was to determine the effectiveness of using a mobile learning platform for students' entrepreneurial competence improvement. The platform was implemented by the Russian State Vocational Pedagogical University and the Financial University under the Government of the Russian Federation. It allowed users to publish assignments, exchange ideas, generate photo and video content, demonstrate creative developments, and receive feedback. The research process enrolled 70 experimental group students, 25 control group students, 2 instructors, and 2 administrators from the considered educational institutions, as well as 3 practitioners invited to review projects. As a result of this examination (Cronbach's alpha ranged from 0.678 to 0.714 ), it was noted that $41.4 \%$ of all research participants rather agreed that the experiment goals were accomplished and noted personal progress in mastering entrepreneurial competences, whereas $53.4 \%$ agreed unequivocally that the experiment was fully successful. Analysis of entrepreneurial competences and deviations from repeated competence evaluations before and after the experiment revealed that the experimental group was marked with notable progress $(F(1.32)$ $=42.26, p=0.00, \eta_{2}^{p}=0.56$ ). Average entrepreneurial competence assessment results for this group were slightly higher than those for control - they constituted 4.5 points against 4.0 . Research findings are believed to be universal and interesting to educators and administrative staff of educational institutions or those involved in creating and conducting entrepreneurship training courses.
\end{abstract}

Keywords - Entrepreneurship education, mobile learning platforms, mobile technologies, digital education, entrepreneurial competences 


\section{Introduction}

In the modern globalized world, knowledge, innovations, and entrepreneurship remain critical for the development of both the economy and society. Due to declining employment opportunities and a trend towards making education more creative, the demand for entrepreneurship education is increasing [1]. Those who have entrepreneurial skills and therefore can identify challenges and take prompt measures to promote social and economic welfare are proved to make the modern world better. Entrepreneurship education is seen as the main driving force for entrepreneurial competence development [2]. Initially, the main goal of entrepreneurship education was to stimulate students to launch a startup, but more recently, the focus has been shifted to a broader concept that denotes entrepreneurship as a way of thinking and behaving. The pros of specialized entrepreneurship training are not limited to startups, innovative business activity, and new employment opportunities, but rather the person's ability to turn bright ideas into actions [3]. To achieve sustainable growth and additional jobs, one should be ready to invest in entrepreneurship education and inspire young people to think outside the box [1].

Entrepreneurship is now referred to as one of the modern and serious challenges in vocational training [4]. Universities face the problem of preparing students for work in the labor market, where the ability to act and think in an entrepreneurial and proactive manner is critical for success. Educational institutions are widely regarded as an environment that stimulates and supports students in developing entrepreneurial skills and knowledge. For this reason, universities are currently changing the way they communicate with students. Today, they are more likely to adopt a student-centered model of delivering training material and thereby improve and update communication through a mobile learning environment [5] with a steadily growing number of educational applications [6]. The digital revolution has led students to prefer learning with mobile devices and platforms that have become an integral part of their lives. New technological solutions foster student-centered learning, encourage demand and creativity, and expand access to research and teaching materials regardless of time and place of training [7].

Emerging educational challenges pose educators the unprecedented difficulty of formulating integrated learning and teaching strategy that aligns anticipated learning outcomes with effective pedagogical decisions [8]. The solution to the problem of training entrepreneurs is largely associated with introducing adequate information and communication technologies (ICT) in educational institutions and the ability to integrate ICT into entrepreneurship curricula. It is essential to determine possible ways to systematically develop entrepreneurial competences, including through the introduction of mobile learning platforms. Therefore, this study aims to assess the prospects of introducing a mobile learning platform into entrepreneurship education to increase teaching effectiveness and stimulate the development of students' entrepreneurial thinking and competence. For this, the article will consider conceptual issues of the evolution of entrepreneurial education (Section 2.1), the development of students' entrepreneurial competences (Section 2.2.), opportunities and challenges of mobile technologies in education (Section 2.3), their role in the formation of entrepreneurial competences in higher 
education (Section 2.4), as well as methodological approaches, results, discussion points, and research conclusions.

\section{Conceptual Background and Theory}

\subsection{Entrepreneurship education in the 21st century}

Apart from the central role of universities focused on teaching and research, they have another mission seeking to provide an interaction between the educational institution and public via innovations, technology transfer, lifelong learning, and social responsibility tools [9]. Spreading an entrepreneurial culture in universities is crucial since entrepreneurial behavior can be developed only through practice, experience, and assimilation of structured knowledge gained in the classroom [3,10]. Among the major obstacles to a common understanding of entrepreneurship is the different approach to this notion. The first most popular idea deals with a person trying to create his/her own business. In contrast, the second is about an individual who explores and benefits from opportunities and possesses competences that can be used to create value for others [11]. Against this background, starting and running a business represents a "narrow approach" to entrepreneurship, whereas exploring and using opportunities together with entrepreneurial competences denote the "broad approach" [12].

The effect of investment in human capital depends largely on the type of investment made [13]. In entrepreneurship education, this means that the features of the curriculum affect the efforts put into learning. Generally, the pedagogy of entrepreneurship education can be divided into "practice-oriented" and "theoretical-oriented." In the case of the second approach, the student represents a passive knowledge recipient, and the instructor is viewed as a learning initiator. In contrast, in the educational model oriented on practice, the student is in charge of constructing learning based on his/her experience [14]. To achieve this, the educational process can be based on a "practice-oriented" approach that aims to recreate the entrepreneurial context to place entrepreneurs in the professional environment [14]. This approach makes it possible to assess the value of what has been learned in specific applications [15]. Different approaches set entrepreneurship education different goals: support new business management and develop innovative, creative, and entrepreneurial people [16]. In such a manner, entrepreneurship education can be seen as a process of training aimed at entrepreneurial competence development. In other words, it identifies, assesses, and exploits capabilities to create value for the economy, society, and culture, as well as stimulates the development of competences related to the creation, management, and scaling of enterprises. Entrepreneurship education is perceived as a key process assisting students in acquiring entrepreneurial knowledge to identify entrepreneurial opportunities and implement them.

Entrepreneurship education should promote student abilities to generate innovations and ideas, implement skills and knowledge, and create effective enterprises. It is an educational process that transfers information and skills to learners to teach them to identify investment opportunities, entrepreneurial strategies and achieve business success [17]. In the process of learning, entrepreneurial spirit and thinking are activated, 
allowing students to acquire important skills and thus work productively, benefiting themselves and society and developing a successful business [17]. Entrepreneurship education brings students closer to real working conditions. This has made it prevalent in the global curriculum, particularly in developing countries, where the unemployment rate is high, and issues related to job creation, wealth, and economic viability are especially acute [18]. A number of higher educational institutions are setting up Entrepreneurship Development Centers to coordinate learning and help graduates start a profitable business regardless of the study field, skills, and knowledge if they cannot secure employment in the public or private sector. The challenge of entrepreneurship education lies in offering both codified and implicit elements that are able to make up entrepreneurial experience and knowledge resulting from the learning process.

\subsection{Development of students' entrepreneurial competence in modern higher education}

There are a number of definitions and classifications associated with the concept of competence. Representatives of the world scientific community define competence as a set of knowledge, skills, and attitudes important in achieving desired results (task completion) in certain contexts. They highlight an aspect of action, describing it as an ability to act now and in the future, as well as to take responsibility. Competence is also viewed as knowledge, skills, and attitudes conditioned by the solution of problems, as well as the ability to operate in a particular profession, organization, work, and situation effectively [19]. Thus, it can be argued that entrepreneurial competence is widely regarded as a series of integrated abilities, consisting of knowledge, skills, and attitudes necessary to perform the entrepreneurial job and new value creation [20]. The broad approach to this term includes a sense of initiative, creativity, negotiation skills, ability to work individually and in a team, leadership qualities [21], and the development and support of entrepreneurial thinking [22]. Competence models provide a platform for incorporating different interpretations, learning outcomes, and entrepreneurship learning roles. Competence model analysis facilitates understanding how good entrepreneurship performance can be achieved throughout all levels of education. The most widely accepted model is represented as a six-tier pyramid consisting of personal effectiveness competences, academic competences, workplace competences, industrywide technical competences, industry-sector technical competences, and management competences.

No less important role in entrepreneurial competence development is assigned to teamwork, individuals with multidisciplinary competences [23], human and social capital, and those talented in marketing [24]. Particular attention is also paid to the need to promote initiatives aimed at developing entrepreneurial competences in the following key areas: entrepreneurial (the process of identifying, evaluating and exploring business opportunities), operational and contextual (knowledge and skills required to launch a startup), and conceptual (action-oriented attitudes and skills) [25]. The basic and generally accepted organization of entrepreneurial competences in a spiral of three spheres includes ideas and opportunities (vision, creativity), resources (motivation, mobilizing resources, etc.), and actions (initiative, experience-based 
learning, etc.) [26]. However, in recent years other approaches with new levels have appeared [27]. Modernized models tend to have four (achievement, personal power, planning, relationship building) and sometimes five dimensions (plus innovation) [28]. The rating of key individual competences based on the Delphi method makes it possible to infer that the most significant competences are risk assumption, initiative, leadership, teamwork, responsibility, autonomy, self-confidence, integrity, negotiation, and dynamism [29]. At the same time, competences related to efficiency, change management, and social mobility have equal weight [30]. In any case, initially, a competence model created for a particular educational system is unlikely to correspond to other systems' needs and goals, and thus it is advised to adapt such models to specific needs [31].

In the light of the possible gradual development of entrepreneurial competence, learning outcomes should be set with regard to potential target groups, which involves consideration of numerous variables of the competence development process and makes the assessment and measurement of competences a challenging and interesting task. Despite the importance of entrepreneurship education, the growing number and heterogeneity of the content and entrepreneurship education proposals, as well as curriculum recommendations developed by a number of scholars, research is largely unable to reveal the most effective way of studying entrepreneurship [32]. Reported effects vary - most researchers declare a positive relationship between entrepreneurial and e-learning outcomes indicating that it improves entrepreneurial skills of learners, while other scholars have found mixed or insignificant relationships [33].

\subsection{Opportunities and challenges of using mobile technologies in education}

Technology-based pedagogy takes considerable advantage of technological solutions to deliver high-quality education [34]. Innovations can significantly improve the student experience and give rise to the exponential development of software and artificial intelligence technologies to adapt curricula to each student's abilities [35]. Technological innovations are proved to be among the most effective tools for developing knowledge and skills. As the demand for entrepreneurial skills grows, their role in entrepreneurship education increases, offering a more flexible approach to training and students' engagement [36]. In modern conditions, innovative technologies are critical to achieving the goal of entrepreneurship education as they allow students to access online resources and share creative ideas with a world community. Educating aspiring entrepreneurs requires progressive solutions that allow acquiring novel digital skills to expand job opportunities in the market [16].

Mobile learning is the use of mobile technology for educational purposes. The implementation of the educational concept provides for the use of portable devices to learn and exchange ideas not only in the distance learning environment but also while traveling or walking. The prevalence of mobile learning has led to the emergence of a large number of sophisticated mobile devices with applications supporting mobile learning scenarios [37]. Mobile learning (with the use of smartphones, tablets, iPads and other portable devices) also refers to the integration and application of portable mobile de- 
vices to facilitate teaching. It enhances students' interest in training, provides educational content in various formats [38], and has the potential to adjust the learning environment to different social groups [39]. The use of mobile devices for educational purposes is shaping a new culture and style of pedagogy, allowing instructors and students to interact and communicate more closely. However, the introduction of mobile learning also faces some challenges (Table 1).

Table 1. Mobile learning challenges

\begin{tabular}{|l|l|}
\hline \multicolumn{1}{|c|}{ Challenge type } & \multicolumn{1}{c|}{ Identified problems } \\
\hline Technical challenges & $\begin{array}{l}\text { Network connectivity and bandwidth, poor battery life, small screen and insuffi- } \\
\text { cient memory size, uncomfortable layout of the content compared to that on a } \\
\text { PC/laptop, limited support for some file formats }\end{array}$ \\
\hline Security challenges & $\begin{array}{l}\text { Poor content security, piracy and copyright infringement, possibility of device theft } \\
\text { or misuse, viruses and malicious software }\end{array}$ \\
\hline Social challenges & $\begin{array}{l}\text { Inability to afford the device due to its expensiveness, lack of basic user skills, } \\
\text { poor opportunities for the disadvantaged and disabled, lack of confidence in ICT } \\
\text { use }\end{array}$ \\
\hline Pedagogical challenges & $\begin{array}{l}\text { Adaptation of available e-learning resources, the ability to deliver educational con- } \\
\text { tent, shift from instructor-centered learning to student-instructor learning, evalua- } \\
\text { tion of out-of-school learning content, bridging the gap between online and mobile } \\
\text { learning, planning and introducing innovations for lifelong education, evaluation of } \\
\text { the results of the implementation of m-learning }\end{array}$ \\
\hline $\begin{array}{l}\text { Specific challenges in } \\
\text { developing countries }\end{array}$ & $\begin{array}{l}\text { Poverty, lack of infrastructure and network problems, neglect of education by } \\
\text { stakeholders, limited access to technology, low educators' awareness }\end{array}$ \\
\hline
\end{tabular}

Note: Compiled based on Oyelere et al. [7].

Although education is currently moving towards technology-based learning and the relationship between education and technology is strengthening, one should not forget that entrepreneurship as an occupation encompasses many professions. Universities can find it challenging to provide all the necessary technological capacities to educate all professions due to limited resources and prohibitions of some educational institutions' policies on the use of mobile phones in classrooms [40].

\subsection{Mobile technologies and their role in entrepreneurship education}

It is believed that in-class activities should correspond to an ICT-driven environment that shapes and changes the learning space, learning content, and the process of acquiring new knowledge and skills [41]. Entrepreneurship pedagogy is an educational strategy used to teach and evaluate entrepreneurship by exploring appropriate learning models (experimental, constructivist, demand-driven) [42]. Since innovative business ideas are expected to be sold, the use of cutting-edge solutions in preparing future entrepreneurs is a must. They provide students with digital marketing, strategic planning, and other skills necessary to develop a business [43]. The use of mobile phones and other portable devices offers tremendous learning opportunities. Most students get using digital technologies in their studies and everyday life into the habit [44]. As a consequence, digital teaching materials are also becoming more accessible these days. Smartphones and other devices are gradually changing the pedagogy of entrepreneurship, and now it uses innovative approaches to education that foster the integration of technology and 
diversify learning experiences. Educators rightfully state that it is important to exploit technology's potential fully to arouse students' interest in entrepreneurship and help them achieve their goals [45].

The application of modern technologies in entrepreneurship education promotes the development and implementation of experiential learning that inspires students to think creatively. High-tech learning platforms, including those for mobile education described in this study, can create a motivational environment where students can easily demonstrate creative talents and entrepreneurial skills. Mobile platforms create opportunities for brainstorming, promoting ideas, and shaping an entrepreneurial experience. Technology makes collaborative entrepreneurship learning easy and flexible in terms of learning time and place. The introduction of ICT in entrepreneurship education has shifted the emphasis to practical learning methods that are useful for building hands-on experience. Modern entrepreneurship pedagogy requires extensive use of technology [24] as it has the potential to influence entrepreneurship learning outcomes. Platforms, such as YouTube or Facebook, make it possible to integrate photos and videos and other content into the educational process to improve the course content and teaching methods.

To realize the goals of entrepreneurship education in the 21 st century, educators should make the most of the capabilities of mobile learning platforms allowing students and faculty to create content, share knowledge, interact, and acquire skills of solving real-life problems.

The benefits of mobile learning lie in ubiquitous learning and improved usability, opportunities for continuous learning regardless of time and location, and increased communication and interaction between students and educators. Some students are particularly attracted to novel technological advancements, interesting opportunities, and useful mobile-based educational applications [7]. A fascinating learning environment motivates individuals to immerse themselves in the training process. The implementation of mobile learning that includes automatic progress tracking can be a robust solution to the problem of hectic scheduling. Besides, learning progress can be easily tracked when learners are engaged through a mobile device. The generalization of studies on mobile technologies in entrepreneurship education makes it possible to conclude about their increasing potential and the need to expand the theoretical and practical base in the field.

\section{$3 \quad$ Materials and Methods}

\subsection{Sample formation}

The research sample included 70 students, 2 educators, and 2 administrators from the Russian State Vocational Pedagogical University and the Financial University under the Government of the Russian Federation, as well as 3 practitioners invited to review projects. In addition, there was a control group of students studying entrepreneurship in the traditional in-class format consisting of 25 people.

The distribution of students in the experimental group by gender is shown in Fig. 1. 


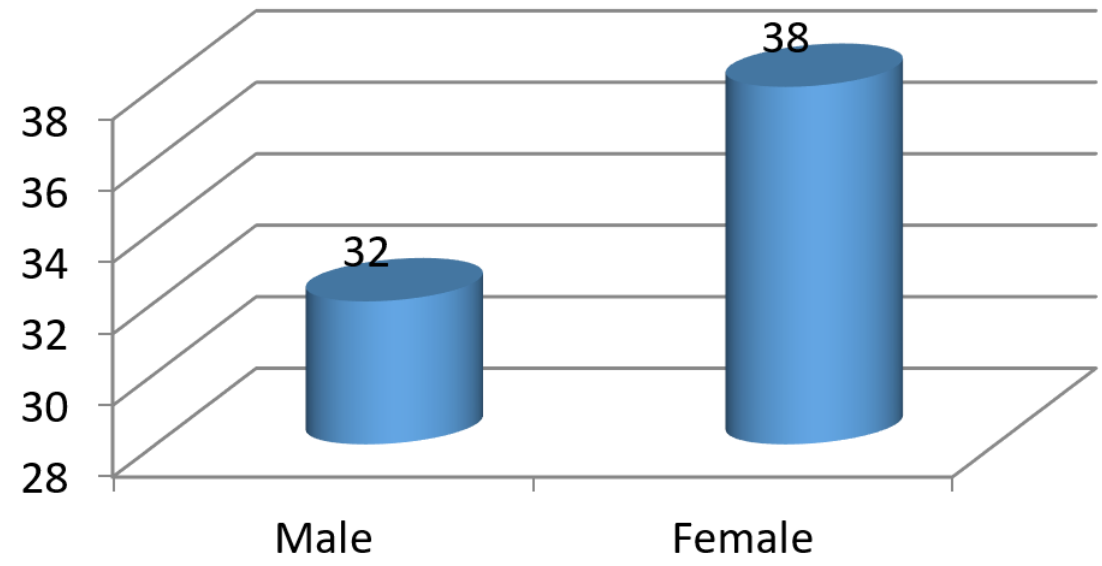

Fig. 1. Distribution of students by gender

Note: Developed by the authors

Research sample consisted of $32(45.7 \%)$ males and 38 (54.3\%) females. The average age of the students who took part in the experiment was 20.5 years.

\subsection{Research methods}

The research process presupposed conducting an interview to analyze the opinions of students on the possibilities and prospects of the mobile learning platform tested within an entrepreneurship education course. For this, the psychometric Likert scale was used [46].

The respondents assessed various aspects using a five-point scale. The points assigned can be interpreted as follows:

- "1" - Means that the respondent strongly disagrees that the goal of the study or progress in the formation of entrepreneurial competence was achieved

- " 2 " - Means that the respondent rather disagrees with the fact that the research goal was achieved and feels no tangible progress in the competence formation

- "3" - Means that the respondent finds it difficult to assess the achievement of research goals and progress in the formation of entrepreneurial competence

- " 4 " - Means that the respondent rather agrees that the study objectives were achieved and notes progress in the formation of competence

- "5" - Means that the respondent fully agrees that the goal was achieved and the progress in the formation of entrepreneurship competence is clearly seen.

Entrepreneurial competence was measured based on a test with open-ended questions, two types of questionnaires (the first, multiple-choice one, to assess entrepreneurial knowledge and the second, open question, to measure self-esteem and entrepreneurial experience), and an expert assessment of the final course projects. 


\subsection{Research tools}

The processes of analytical data collecting, statistical data processing, and identification of specific trends and relationships were carried out utilizing the Statistical Package for the Social Sciences (SPSS). With the help of SPSS tools for demographic variables, an analysis of deviations from repeated measurements was performed when assessing the impact of training via mobile learning platform on research participants' entrepreneurial competence.

The consistency of the items included in the multiple-choice questionnaire was analyzed with the Cronbach's alpha test. Given that its coefficients' values ranged from 0.678 to 0.714 , a conclusion about the good internal consistency of the questionnaire can be made.

\subsection{Research design}

In the course of the experiment that lasted one academic semester during the 20192020 academic year, the mobile learning platform for entrepreneurship education (in the form of a mobile application) was tested. The application was characterized by a user-friendly interface that allows easy interaction with the database; thus, users not very competent in modern technologies could easily use it. The platform was adapted to a variety of smartphones and tablets.

Initially, the participants of the experimental and control groups took a pretest to determine their entrepreneurial competence. Then the control group started to study the entrepreneurship course in a traditional way - the tasks were expected to be solved in the classroom or as homework. The experimental group students implemented a learning plan according to an individual trajectory. The mobile platform provided flexible learning opportunities with checkpoints for various assignments. At the end of the course, all students from the control and experimental groups presented their startup projects and underwent a post-test to determine their entrepreneurial competences.

\subsection{Research limitations}

A number of limitations should be noted. Due to some characteristics of the sample, the study cannot be considered fully representative - the students of the experimental group voluntarily made a decision to participate in the mobile-based course, which excludes random sampling. The most motivated students were self-selected for the experimental program. Another limitation of the study refers to the fact that the test platform was compatible exclusively with Android devices.

\subsection{Ethical issues}

Each research participant agreed for their personal data to be collected and used. At the same time, the information on their achievements was confidential and not disclosed. 


\section{$4 \quad$ Findings}

The development of entrepreneurial competences in experimental group students was performed via the mobile learning platform. The main components of the mobile learning platform and their characteristics are described in Table 2.

Table 2. Main components of the mobile learning platform

\begin{tabular}{|l|l|}
\hline \multicolumn{1}{|c|}{ Component } & \multicolumn{1}{c|}{ Characteristic } \\
\hline Home page & Navigation through the mobile application and links to modules. \\
\hline Registration page & $\begin{array}{l}\text { Allows users to register on the platform. Required information: name, surname, } \\
\text { phone number, email, login and password. }\end{array}$ \\
\hline Login page & Allows users to log into the system using their username and password. \\
\hline Shared module & $\begin{array}{l}\text { Allows users to upload photos, videos, presentations, completed tasks and text } \\
\text { documents. Users can share materials about their work and get feedback or } \\
\text { recommendations. Instructors can also upload assignments, post notes, videos, and } \\
\text { photos to showcase examples. }\end{array}$ \\
\hline Interaction & $\begin{array}{l}\text { Allows users to view messages left by other users of the platform, make comments } \\
\text { and see reactions to messages. }\end{array}$ \\
\hline Reference & $\begin{array}{l}\text { Contains up-to-date information about entrepreneurship and technical aspects of } \\
\text { learning on the platform. }\end{array}$ \\
\hline Admin panel & $\begin{array}{l}\text { Allows the administrator to manage users, access messages pending approval, and } \\
\text { get feedback. }\end{array}$ \\
\hline
\end{tabular}

Note: developed by the authors

The mobile learning platform was designed as student-centered. The instructor was supposed to act as a tutor who guides the learning process. His/her role was to evaluate students' performance, track their feedback on their user experience, upload materials, participate in discussions, and stimulate students' entrepreneurial potential. Platform users had to complete a registration procedure to ensure the identification and recording of activities and achievements.

The platform allowed users to use modules to share photo and video content, receive feedback and recommendations on a personal learning path. Thus, students were responsible for their learning, which promoted active and demand-driven learning.

In order to improve entrepreneurial competence, a special program to be completed within one academic semester was developed. After each block of the curriculum, there was an assignment, which should be made by students in accordance with their own schedule. The instructor determined the deadline for the assignment to be posted on the platform. After the assignment was posted, it was assessed by other educational process participants, as well as commented and discussed. At the end of the course, the students (pre-distributed in mini-groups of 3-4 people) came up with an idea for a startup solution, which they also substantiated.

In order to evaluate the experiment of introducing a mobile learning platform into the educational process, an analysis was carried out with the application of the elements of applied knowledge and the degree of entrepreneurial competence. To assess the impact of the mobile learning platform on the entrepreneurial competence of participants, an analysis of deviations from repeated measurements was performed. The results of 
measuring competence before and after the test were compared in the experimental and control groups (Fig. 2).

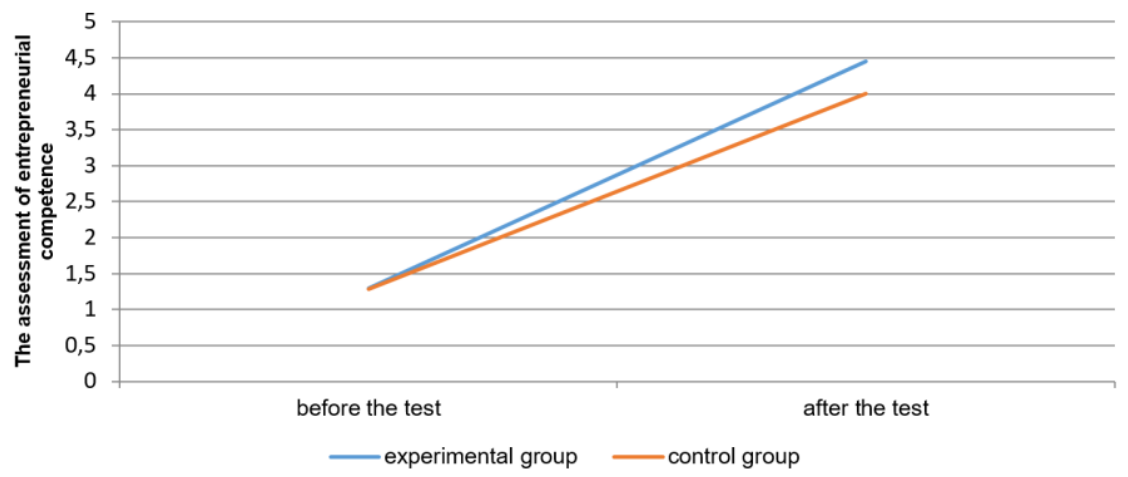

Fig. 2. The effect of training based on the mobile learning platform

Note: developed by the authors

The starting assessments of participants from the control and experimental groups were the same. It is notable that after one academic semester of the mobile-based course, average entrepreneurial competence assessment results in the experimental group were slightly higher - they constituted 4.5 points against 4.0 in the control group (with a general upward trend). Apart from this, positive development of entrepreneurial competence was noted in the experimental group $\left(F(1.32)=42.26, p=0.00, \eta_{2}^{p}=0.56\right)$.

According to the results of the interviews, most respondents agree with the need to introduce a mobile learning platform to implement distance entrepreneurship programs. Respondents also agreed with the assertion that the traditional approach does not meet the modern needs when teaching entrepreneurial skills and knowledge and that there is an objective need to introduce a more flexible digital approach to learning (Fig. 3). 


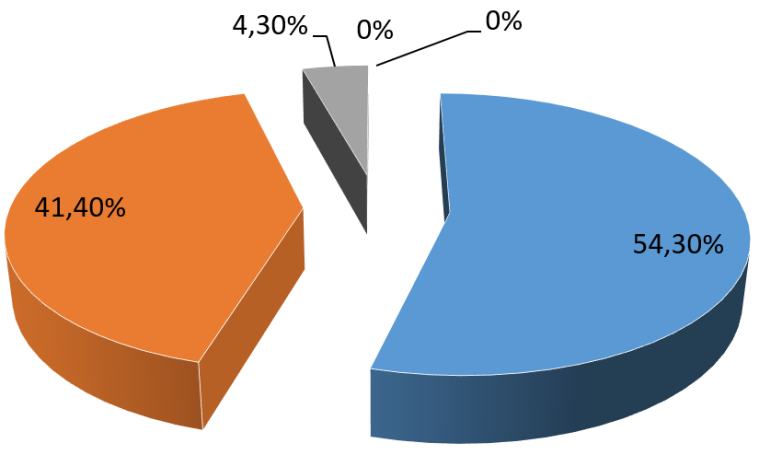

$\square$ Completely agree $\square$ Rather agree $\quad$ Not sure $\square$ Rather disagree $\square$ Disagree

Fig. 3. Results of a survey of respondents on the need to implement a mobile learning platform in entrepreneurship education

Note: developed by the authors

Thus, according to the survey results, there were no respondents who "disagreed" and "rather disagreed." This allows the conclusion that all students noticed the usefulness of mobile entrepreneurship education. The degree to which students perceived its value differed; however, a tendency to high scores when filling out the questionnaires was evident. Three people (4.3\%) found it difficult to answer. They explained their position by the fact that it is possible to achieve the same academic outcomes in the traditional learning environment. In the process of mobile learning, these students had difficulties with self-organization. They added that they were more productive when being constantly guided by the instructor in the class according to the established schedule. Among all the cohort, 29 students (41.4\%) "rather agreed," and 38 people "completely agreed" that this experience was useful and the experiment achieved the goal of a more active formation of entrepreneurial competence.

It should also be noted that according to the results of startup projects' development, two groups of students who worked in a team received an offer to support the proposed idea from the practitioners (entrepreneurs) invited.

\section{Discussion}

Research findings show that the range of values, motives, and competences associated with entrepreneurial activity can develop, and education can play a central role in this process [47]. While expanding the existing outcomes in the field, this study confirms that entrepreneurial skills can emerge before engaging in entrepreneurial activity as a profession [31]. Testing entrepreneurial competences obtained as a result of the 
mobile learning course yielded results that correlate with the outcomes of a psychometric test measuring entrepreneurs' personal qualities [48]. The present research reinforces recent findings declaring that people possessing network and professional adaptation skills are more likely to demonstrate entrepreneurial behavior [49]. Investigation of the impact of the five dimensions of entrepreneurial skills led to the conclusion that they are positively correlated with the success of micro-entrepreneurship [50] and small firms' effectiveness [51].

The outcomes obtained also support the judgment that innovative entrepreneurship education positively influences students' entrepreneurial spirit and may entail a more directed orientation of students towards social benefits that the entrepreneurship activity brings [52]. Alongside this, there is evidence that not all countries have students using a mobile phone to access various activities due to mobile access limitations in terms of usability and reliability [53,54]. In general, the effectiveness of mobile learning in developing entrepreneurial competences was proven [55].

The practice of introducing a model of key entrepreneurial competences based on soft-computing (SKECM) and a three-cluster approach used by Empretec seems promising in this field. The reason is that this model aims to develop students' entrepreneurial competence in the context of suddenly changing situations [56]. Another interesting idea lies in the human capital theory suggesting that exposure to various entrepreneurship education initiatives has an inverted U-shaped relationship with entrepreneurial learning outcomes [57]. This point was confirmed by a multilevel analysis conducted among 87,918 students within the Global University Entrepreneurial Spirit Students' Survey. A separate area in the study of entrepreneurship education is devoted to games, which are widely used for developing such entrepreneurial skills as strategic management, leadership, communication, negotiation, and decision-making. In this regard, a serious game FLIGBY is gaining much attention. In particular, Fernando and Buzady [58] have investigated whether the competences developed and assessed by virtue of FLIGBY can be further used to evaluate students' entrepreneurial abilities within the entrepreneurship course in a higher education institution.

\section{Conclusion}

Preparing highly-professional entrepreneurs is an essential step in combating unemployment that emerged under the current crisis and limited educational opportunities arisen out of the global Covid-19 pandemic. Against this backdrop, the present study identified particular functional capabilities of mobile technologies that can beneficially influence the quality of entrepreneurship education. A mobile learning platform was defined as necessary to create a more engaging, creative, and effective entrepreneurship training program. Its implementation was proved to encourage active students' participation in learning and help educators to activate students' creative thinking and generate new content and ideas. In total, this applied and descriptive research showed a positive relationship between mobile-based entrepreneurship education and improvement of adaptability, network skills, professional self-efficacy, creative thinking, and entrepreneurial behavior of students involved. 
Within the framework of this study, all the individuals enrolled were surveyed on the need to implement mobile learning technologies in entrepreneurship education. The survey had high reliability and consistency of the items (Cronbach's alpha coefficients ranged from 0.678 to 0.714 ) and revealed neither strong nor mild disagreement with the necessity to introduce mobile learning. Most experimental group respondents (underwent experimental mobile learning course) claimed about the progress in entrepreneurial competence formation. Only $4.3 \%$ of them found it difficult to assess the impact of the proposed methodology; $41.4 \%$ rather agreed that the experiment objectives were achieved and noted personal progress in mastering entrepreneurial competence; whereas $53.4 \%$ agreed without the slightest doubt that the experiment was fully successful.

The results of the preliminary and secondary evaluations of students' competences were also quite inspiring. The statistical data of pre- and post-test analysis showed reliable results. In particular, the experimental group was marked with an improvement in entrepreneurial competence $\left(F(1.32)=42.26, p=0.00, \eta_{2}^{p}=0.56\right)$. After the end of mobile-based training, the average entrepreneurial competence assessment results in the experimental group were somewhat higher than those in the control group (4.5 points against 4.0, with a general upward trend).

The main research limitation was connected with the fact that the desire to be engaged in a mobile-based course was expressed by the most motivated students. This particular event could affect the final score. At the same time, research results are universal and may be of interest to educators and administrative staff of educational institutions or people involved in developing or conducting entrepreneurship training courses.

\section{$7 \quad$ References}

[1] Haara, F.O., Jenssen, E.S. (2016). Pedagogical entrepreneurship in teacher education-what and why? Icelandic Journal of Education, 25(2): 183-196.

[2] European Commission (2016). Eurydice Entrepreneurship Education at School in Europe. Eurydice Report. Luxembourg: Publications Office of the European Union. https://eacea.ec.europa.eu/national-policies/eurydice/content/entrepreneurship-educationschool-europe_en. https://doi.org/10.5944/reec.22.2013.9333

[3] Baptista, R., Naia, A. (2015). Entrepreneurship education: A selective examination of the literature. Foundations and Trends in Entrepreneurship, 11(5): 337-426. https://doi.org/10. $\underline{1561 / 0300000047}$

[4] Narikbaeva, L.M., Savenkov, A.I. (2016). Pedagogical System of Students Vocational Ability Development. International Journal of Environmental and Science Education, 11(9), 3013-3024.

[5] Hassan, M.H., Alhosban, F., Hourani, M.A. (2016). Using mobile technologies for enhancing student academic experience: University of Jordan case study. International Journal of Interactive Mobile Technologies, 10(1): 13-18. https://doi.org/10.3991/ijim.v10i1.4809

[6] Papadakis, S., Vaiopoulou, J., Kalogiannakis, M., Stamovlasis, D. (2020). Developing and Exploring an Evaluation Tool for Educational Apps (E.T.E.A.) Targeting Kindergarten Children. Sustainability, 12: 4201. https://doi.org/10.3390/su12104201 
[7] Oyelere, S.S., Suhonen, J., Sutinen, E. (2016). M-Learning: A new paradigm of learning ICT in Nigeria. International Journal of Interactive Mobile Technologies, 10(1): 35-44. https://doi.org/10.3991/ijim.v10i1.4872

[8] Wu, Y.J., Yuan, C.H., Pan, C.I. (2018). Entrepreneurship education: An experimental study with information and communication technology. Sustainability, 10(3): 691. https://doi.org/ $\underline{10.3390 / \mathrm{su} 10030691}$

[9] Loi, M., Di Guardo, M.C. (2015). The third mission of universities: An investigation of the espoused values. Science and Public Policy, 42(6): 855-870. https://doi.org/10.1093/ $\underline{\text { scipol/scv012 }}$

[10] Ghina, A. (2014). Effectiveness of entrepreneurship education in higher education institutions. Procedia-Social and Behavioral Sciences, 115: 332-345. https://doi.org/10.1016/j. sbspro.2014.02.440

[11] Moberg, K., Stenberg, E., Vestergaard, L. (2014). Impact of EE in Denmark. The Danish Foundation for Entrepreneurship - Young Enterprise. http://www.cise.es/wp-content/uploads/2013/03/5.-impact_of_entrepreneurship_education_in_denmark_2011.pdf. $\underline{\text { https:// }}$ doi.org/10.18411/a-2017-023

[12] Rasmussen, A., Fritzmer, A. (2016). From dream to reality: Learning outcomes and didactic principles for teaching entrepreneurship in Nordic schools. Copenhagen: Nordic Council of Ministers.

[13] Marvel, M.R., Davis, J.L., Sproul, C.R. (2016). Human capital and entrepreneurship research: A critical review and future directions. Entrepreneurship Theory and Practice, 40(3): 599-626. https://doi.org/10.1111/etap.12136

[14] Gielnik, M.M., Frese, M., Kahara-Kawuki, A., Wasswa Katono, I., Kyejjusa, S., Ngoma, M., Oyugi, J. (2015). Action and action-regulation in entrepreneurship: Evaluating a student training for promoting entrepreneurship. Academy of Management Learning \& Education, 14(1): 69-94. https://doi.org/10.5465/amle.2012.0107

[15] Mueller, S., Anderson, A.R. (2014). Understanding the entrepreneurial learning process and its impact on students' personal development: A European perspective. The International Journal of Management Education, 12(3): 500-511. https://doi.org/10.1016/j.ijme.2014. $\underline{05.003}$

[16] Vestergaard, L. (2015). Entrepreneurship in Education in the Baltic Sea Region. EU Strategy for the Baltic Sea Region. http://www.ffe-ye.dk/media/492194/entrepreneurship-in-education.pdf

[17] Moses, C., Akinbode, M., Olokundun, A.M., Agboola, M.G. (2015). Entrepreneurship education and action-oriented pedagogical approaches. International Journal of Educational Science and Research, 5(5): 53-60.

[18] Gibb, A., Price, A. (2014). A compendium of pedagogies for teaching entrepreneurship. International entrepreneurship educators program.

[19] Nair, S., Sundar, S., Paramasivam, G.M. (2020). Role of entrepreneurial education in nurturing entrepreneurial orientation among engineering students. Asia Pacific Journal of Innovation and Entrepreneurship, 14(2): 139-149. https://doi.org/10.1108/apjie-05-2019-0031

[20] Kommers, P. (2019). Guide Entrepreneurial Education Guide - Entrepreneurial Education. Project: IV4J Project. Erasmus+ Programme of the European Union. https://www.researchgate.net/publication/334173577_GUIDE_ENTREPRENEURIAL_EDUCATION Guide__Entrepreneurial_Education. https://doi.org/10.4000/books.pressesmines.3475

[21] Grib, E.V., Kolomoets, E.N., Latysheva, V.V. (2020). Game-based methods for competence teamwork and leadership development: The case of engineering students. Vysshee Obrazovanie v Rossii, 29(10): 125-134. https://doi.org/10.31992/0869-3617-2020-29-10-125$\underline{134}$ 
[22] Blenker, P., Korsgaard, S., Neergaard, H., Thrane, C. (2011). The questions we care about: paradigms and progression in entrepreneurship education. Industry and Higher Education, 25(6): 417-427. https://doi.org/10.5367/ihe.2011.0065

[23] Jin, L., Madison, K., Kraiczy, N.D., Kellermanns, F.W., Crook, T.R., Xi, J. (2017). Entrepreneurial team composition characteristics and new venture performance: A meta-analysis. Entrepreneurship Theory and Practice, 41(5): 743-771. https://doi.org/10.1111/etap.12232

[24] Yoon, H. (2018). Exploring the role of entrepreneurial team characteristics on entrepreneurial orientation. SAGE Open, 8(2): 1-14. https://doi.org/10.1177/2158244018777025

[25] Komarkova, I., Gagliardi, D., Conrads, J., Collado, A. (2015). Entrepreneurship Competence: An Overview of Existing Concepts, Policies and Initiatives. JRC Science and Policy Report. http://publications.jrc.ec.europa.eu/repository/bitstream/JRC96531/jrc96531 final. pdf

[26] Bacigalupo, M., Kampylis, P., Punie, Y., Brande, G. (2016). EntreComp: The Entrepreneurship Competence Framework. JRC Science for Policy Report. http://publications.jrc.ec.europa.eu/repository/bitstream/JRC101581/lfna27939enn.pdf

[27] Smith, G., Shankar, A., (2015). Empowered entrepreneur training handbook. The Global Alliance for Clean Cookstoves. https://www.cleancookingalliance.org/resources/342.html

[28] Sugars, B. (2014). 12 Essential characteristics of an entrepreneur. https://www.business.com/images/content/58a/d9f1f2f87b1207f720c3d/0-0-/

[29] Robles, L., Zárraga-Rodriguez, M. (2015). Key Competences for Entrepreneurship. Procedia Economics and Finance, 23: 828-832. https://doi.org/10.1016/s2212-5671(15)00389-5

[30] Zarefard, M., Beri, S.E.C. (2017). Relationship between entrepreneurs' managerial competences and innovative start-up intentions in university students: an Iranian case. International Journal of Entrepreneurship, 21(3): 1-19.

[31] Lilleväli, U., Täks, M. (2017). Competence models as a tool for conceptualizing the systematic process of entrepreneurship competence development. Education Research International, 2017: 5160863. https://doi.org/10.1155/2017/5160863

[32] Fayolle, A., Gailly, B. (2015). The impact of entrepreneurship education on entrepreneurial attitudes and intention: Hysteresis and persistence. Journal of small business management, 53(1): 75-93. https://doi.org/10.1111/jsbm.12065

[33] Rauch, A., Hulsink, W. (2015). Putting entrepreneurship education where the intention to act lies: An investigation into the impact of entrepreneurship education on entrepreneurial behavior. Academy of management learning \& education, 14(2): 187-204. https://doi.org/ 10.5465/amle.2012.0293

[34] Oliveira, A., Feyzi Behnagh, R., Ni, L., Mohsinah, A.A., Burgess, K.J., Guo, L. (2019). Emerging technologies as pedagogical tools for teaching and learning science: A literature review. Human Behavior and Emerging Technologies, 1(2): 149-160. https://doi.org/10. $1002 /$ hbe 2.141

[35] Mellul, C. (2019). Emerging Technologies in Higher Education and the Workplace: An Assessment. International Federation of Catholic Universities Higher Education Foresight Unit. https://www.fiuc.org/bdf/pdf/body of text mep1.pdf

[36] Dhital, H. (2018). Opportunities and Challenges to Use ICT in Government School Education of Nepal. International Journal of Innovative Research in Computer and Communication Engineering, 6(4): 3215-3220.

[37] Papadakis, S. (2020). Tools for evaluating educational apps for young children: a systematic review of the literature. Interactive Technology and Smart Education, in press. https://doi. org/10.1108/itse-08-2020-0127

[38] Praveen, G.K., Vasimalairaja, M. (2019). Mobile Learning. Book-Digital Education, 1: $97-$ 105. 
[39] Drolia, M., Sifaki, E., Papadakis, S., Kalogiannakis, M. (2020). An Overview of Mobile Learning for Refugee Students: Juxtaposing Refugee Needs with Mobile Applications' Characteristics. Challenges, 11(2): 31. https://doi.org/10.3390/challe11020031

[40] Tess, P.A. (2013). The role of social media in higher education classes (real and virtual)-A literature review. Computers in human behavior, 29(5): 60-68. https://doi.org/10.1016/j.chb. $\underline{2012.12 .032}$

[41] Duruamaku-Dim, J.C., Duruamaku-Dim, G.C.E. (2014). Entrepreneurship Instruction with Information and Communication Technology (ICT) and Improvement of Entrepreneurial Practices in Nigeria for Global Competitiveness. Journal of Modern Education Review, 4(12): 1012-1023. https://doi.org/10.15341/jmer(2155-7993)/12.04.2014/004

[42] Loykie, L.L. (2012). Entrepreneurship Pedagogy. In Encyclopaedia of New Venture Management. Thousand Oaks: SAGE Publishing.

[43] Edeh, M.O. (2019). Opportunities and Challenges of use of Mobile Phone Technology in teaching and learning in Nigeria-A Review. International Journal of Research in Engineering and Innovation, 3(6): 352-358. https://doi.org/10.36037/ijrei.2019.3601

[44] Philippe, M. (2018). Entrepreneurial pedagogy: an Approach for the development of transversal competences. https://www.profweb.ca/en/publications/featured-reports/entrepreneurial-pedagogy-an-approach-for-the-development-of-transversal-competences

[45] Dansy, T., Tunde, O., Gbenga, A. (2014). Entrepreneurship in Higher Education in Nigeria: An Imperative for Sustainable Development. A Journal of the Faculty of Education Lagos State University Journal, 14(1): 11-24.

[46] Taherdoost, H. (2019). What Is the Best Response Scale for Survey and Questionnaire Design; Review of Different Lengths of Rating Scale/Attitude Scale/Likert Scale. Hamed Taherdoost, 8(1): 1-10.

[47] Khorrami, M., Farhadian, H., Abbasi, E. (2018). Determinant competences for emerging educators' entrepreneurial behavior in the Institute of Agricultural Applied-Scientific Education, Iran. Journal of Global Entrepreneurship Research, 8(1): 8. https://doi.org/10.1186/ s40497-018-0096-4

[48] Ismail, M., Ibrahim, A.F., Yaacob, M.R., Zakaria, M.N., Che Razak, R., Yusoff, M.N.H., Kamaruddin, A.N. (2018). Determine entrepreneurial characteristics using mobile android gamer freezer. International Journal of Interactive Mobile Technologies, 12(1): 141-150. https://doi.org/10.3991/ijim.v12i1.7790

[49] Aldrich, H.E., Yang, T. (2014). How do entrepreneurs know what to do? Learning and organizing in new ventures. Journal of Evolutionary Economics, 24(1): 59-82. https://doi.org/ 10.1007/s00191-013-0320-x

[50] Chatterjee, N., Das, N. (2016). A study on the impact of key entrepreneurial skills on business success of Indian micro-entrepreneurs: A case of Jharkhand region. Global Business Review, 17(1): 226-237. https://doi.org/10.1177/0972150915610729

[51] Hashim, N.A.B., Raza, S., Minai, M.S. (2018). Relationship between entrepreneurial competences and small firm performance: are dynamic capabilities the missing link? Academy of Strategic Management Journal, 17(2): 1-10.

[52] Boldureanu, G., Ionescu, A.M., Bercu, A.M., Bedrule-Grigoruță, M.V., Boldureanu, D. (2020). Entrepreneurship education through successful entrepreneurial models in higher education institutions. Sustainability, 12(3): 1267. https://doi.org/10.3390/su12031267

[53] Papadakis, S., Kalogiannakis, M., Sifaki, E., Vidakis, N. (2017). Access moodle using smart mobile phones. A case study in a Greek University. In Interactivity, Game Creation, Design, Learning, and Innovation. Springer, Cham, pp. 376-385. https://doi.org/10.1007/978-3-31976908-0_36 
[54] Papadakis, S., Kalogiannakis, M., Sifaki, E., Vidakis, N. (2018). Evaluating Moodle use via Smart Mobile Phones. A case study in a Greek University. EAI Endorsed Transactions on Creative Technologies, 5(16): 1-9. https://doi.org/10.4108/eai.10-4-2018.156382

[55] da Silva, J.V.V.M., Klein, A.Z. (2020). A Situated M-Learning Perspective to Develop Individual Entrepreneurial Competences. International Journal of Mobile and Blended Learning, 12(3): 1-19. https://doi.org/10.4018/ijmbl.2020070101

[56] Arafeh, L. (2016). An entrepreneurial key competences' model. Journal of Innovation and Entrepreneurship, 5(1): 26.

[57] Mergemeier, L., Moser, J., Flatten, T.C. (2018). The influence of multiple constraints along the venture creation process and on start-up intention in nascent entrepreneurship. Entrepreneurship \& Regional Development, 30(7-8): 848-876. https://doi.org/10.1080/08985626. 2018.1471163

[58] Fernando, A., Buzady, Z. (2019). Assessment of Entrepreneurship Competences through the Use of FLIGBY. Digital Education Review, 35: 151-169.

\section{Authors}

Nataliya Tretyakova is a researcher, Doctor of Education, currently works as an Associate Professor at the Department of Theory and Methods of Physical Culture in Russian State Vocational Pedagogical University, Ekaterinburg, Russian Federation.

Anton Lyzhin is a researcher, $\mathrm{PhD}$ of Pedagogical Sciences, currently holds the position of Vice-rector for Science, Innovation Policy and External Relations in Russian State Vocational Pedagogical University, Ekaterinburg, Russian Federation.

Elena Chubarkova is a researcher, $\mathrm{PhD}$ of Pedagogic, currently holds the position of the Director of Institute of Information System in Russian State Vocational Pedagogical University, Ekaterinburg, Russian Federation.

Mafura Uandykova is a senior researcher at the Department of Economics in Omsk State University by F.M. Dostoevsky, Omsk, Russian Federation.

Marina Lukiyanova is a researcher, PhD of Economics, currently works as an Associate Professor at the Department of Financial Control in Financial University under the Government of the Russian Federation, Moscow, Russian Federation.

Article submitted 2020-12-02. Resubmitted 2021-02-18. Final acceptance 2021-02-19. Final version published as submitted by the authors. 